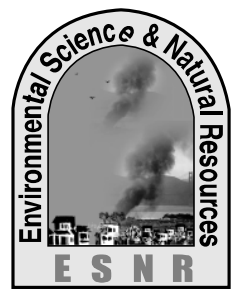

J. Environ. Sci. \& Natural Resources, 6(1): 117 - 121, 2013

ISSN 1999-7361

\title{
Assessment of Iron Contamination in Groundwater at Tangail Municipality, Bangladesh
}

\author{
D. Hossain ${ }^{1}$, M. S. Islam ${ }^{1}$, N. Sultana ${ }^{2}$ and T. R.Tusher ${ }^{1}$ \\ ${ }^{1}$ Department of Environmental Science and Resource Management, Mawlana Bhashani Science and \\ Technology University, Tangail-1902, Bangladesh \\ ${ }^{2}$ Analytical Research Division, Bangladesh Council of Scientific and Industrial Research (BCSIR), \\ Dhaka-1205, Bangladesh
}

\begin{abstract}
The study was conducted to investigate the iron (Fe) contamination in groundwater at Tangail municipality during the period from January to June 2011. Groundwater samples were collected from 18 locations, where 15 were tube-wells, 2 deep tubewells and 1 pump. The result of the study showed that the highest level of Fe $(24.50 \mathrm{mg} / \mathrm{l})$ was found at Dewla north, while the lowest level $(1.03 \mathrm{mg} / \mathrm{l})$ was recorded from Bepari para. The highest and lowest amount of Fe was found in ward 1 and 4 , respectively. The results were compared with the Bangladesh drinking water quality standards as well as with the international standards. In Bangladesh, permissible limit of Fe is $0.3-1.0 \mathrm{mg} / \mathrm{l}$, whereas WHO standard level is $0.3 \mathrm{mg} / \mathrm{l}$. All the samples were exceeded the standard levels of Fe, whereas ward 1, 2 and 7 were worstly affected. The study also reveal that the availability of Fe does not depend on the type of water sources, but it depends on the aquifers or water table. If the aquifer contains Fe, then the tube-well water will contain Fe or vice versa. These higher Fe concentrations found in the study area may be harmful for those families who are consuming the water from these sources on regular basis. Thus, to overcome this problem the consumers should not drink these higher amounts of Fe, and they should find other sources or replace the tube-well or treat the water before drinking and other domestic and household purposes.
\end{abstract}

Key words: Groundwater, Iron, Tube-well, Ward.

\section{Introduction}

Groundwater is an inevitable component of natural resources and plays an important role to serve as many purposes like drinking, irrigation, and other domestic usage (Azad, 2003). Although trends on abstraction and use in each country are not available, globally groundwater is estimated to provide approximately $50 \%$ of current potable water supplies, $40 \%$ of the water demand of self-supplied industry and $20 \%$ of water use in irrigation. Pressures on groundwater resources over the next 25 years in Asia will come from demographic increases, agricultural practices and increasing water demand per capita, coupled with increased urban areas, industrial activity and energy demand (Gunatilaka, 2005). Bangladesh has about 1.8 million hands tube-well for supplying drinking water from underground sources to meet the need of 124 million people (Sattar, 1996). But at present, groundwater of Bangladesh is being contaminated widely by leaching of harmful materials and chemicals from anthropogenic sources, such as unwise application of pesticides and fertilizers, unscientific disposal of waste materials, etc. Heavy metals, most harmful among these chemicals, which are present trace in amount, but have significant effects on drinking water and causes harmful impacts on human health. About $80 \%$ of the diseases in developing countries are related to contaminated water and the resulting death toll is as much as 10 million per year (Anonymous, 2004). Groundwater is contaminated by arsenic (As) in 61 districts of
Bangladesh (Rukshana et al., 2002). It is estimated that more than 20 million people drink water exceeding the national standard for arsenic levels (WARPO, 2000).

The iron contamination in groundwater is one of the most discussed issues as groundwater is an important resource for livelihoods and food security of billions of people. Not only arsenic (As), but also iron (Fe) contamination in groundwater is now a vital problem in Bangladesh. Iron is the second most abundant metal in the earth's crust, of which it accounts for about $5 \%$. Elemental $\mathrm{Fe}$ is rarely found in nature, as the $\mathrm{Fe}$ ions $\mathrm{Fe}^{+2}$ and $\mathrm{Fe}^{+3}$ readily combine with oxygen- and sulfur-containing compounds to form oxides, hydroxides, carbonates, and sulfides. It is most commonly found in nature in the form of its oxides (Elinder, 1986; Knepper, 1981). Most Fe pollution originates from the disposal of waste water following the use of water for any of wide variety of purposes. Thus a large number of sources and causes can modify groundwater quality, ranging from septic tanks to irrigated agriculture (Anon, 1970; Bader, 1973; Ballentine, 1972; Meyer, 1973). Mines can produce a variety of $\mathrm{Fe}$ pollution problem in groundwater (Barnes and Clarke, 1964; Emrich and Merritt, 1969; Mink, 1972). Groundwater in Bangladesh, except in some places, is available at a shallow depth. Groundwater levels are at or near ground level during the period August to October and lowest in April to May. The concentration of $\mathrm{Fe}$ content in the water environment is about $0.27 \mathrm{ppm}$ in 
spring and $0.67 \mathrm{ppm}$ in summer season. In several areas of Bangladesh, groundwater withdrawals are causing a large $\mathrm{Fe}$ contamination in groundwater levels during dry season (Ahmed and Rahman, 2000). As millions of people of Bangladesh rely on groundwater sources for their daily domestic and other purposes, the assessment of groundwater quality is one of the most important tasks. The results of such investigations can minimize different health related problems and can ensure a healthy life with safe drinking water sources. Considering these views, the study was conducted to investigate the $\mathrm{Fe}$ contamination in groundwater at Tangail municipality of Bangladesh.

\section{Materials and Methods}

\section{Study area}

The Tangail municipality was established in 1887, and consists of 18 wards and 63 mahallas with an area of $35.22 \mathrm{~km}^{2}$. There is a population of 128,785 of which male 66,856 and female 61,929. Density of population is 3650 per $\mathrm{km}^{2}$. Though pure water supply was the main objective of the municipality, well and Idara (traditional ring well) was the main sources of water supply in its establishment period. The municipality started water supply system through pipe line after the Pilot Project implemented by the Ministry of Public Health in 1969. At present, there are three overhead tanks (capacity of each 680,000 L), 82,300 hand tube-wells, 7 pump tube-wells (water uplifting power $95,000 \mathrm{~L} / \mathrm{hr}$ ) and 3 treatment plants in the municipality area (Banglapedia, 2008).

\section{Water sample collection}

Water samples were collected from the following 18 places of the municipality out of 18 wards (Table 1). Fifteen samples were collected from tube-well, while two and one sample were collected from deep tubewell and pump tube-well, respectively (Table 2). All the samples were collected in $250 \mathrm{ml}$ plastic bottles with screw cap and well washed before collection to make sure that it is free from any undesirable materials and contaminations. The following processes were followed to wash the bottles, collect and preserve the samples: i) the bottles were washed thoroughly with tap water, then rinsed with distilled water and hydrochloric acid $(\mathrm{HCl})$; ii) the bottles were putted in the oven and dried at $30^{\circ} \mathrm{C}$ for 2 hours; iii) the bottles were completely filled with sample water to the brim; iv) during the filling of sample water to bottles, they were maintained continuously till it was completely filled with sample water and thereby minimize air oxidation; v) then the bottles were tightly screwed and fixed up with cello tape; vi) from each sample, $50 \%$ was preserved by adding 2-3 $\mathrm{ml}$ of $\mathrm{HCI}(0.1 \mathrm{M})$ to control the changing of chemical characteristics of water, then the samples were kept in the laboratory. Finally the samples were brought to Analytical Research Laboratory of the Bangladesh Council of Scientific and Industrial research (BCSIR), Dhaka, Bangladesh, to test the chemical parameters including metal $(\mathrm{Fe})$; vii) all the samples were stored in dark place as far as possible during the sampling and transportation to the laboratory. The samples were preserved again with conc. Nitric acid $\left(\mathrm{HNO}_{3}\right)$ at the rate of $5 \mathrm{ml}$ in each $250 \mathrm{ml}$ bottle (APHA, 1998).

Table 1. Water sampling location in wards of Tangail municipality

\begin{tabular}{|c|c|c|c|c|}
\hline Samples & Sampling sites & Location & Latitude & Longitude \\
\hline 1 & Ward - 01 & Dewla north & $24^{\circ} 16^{\prime} 33.5^{\prime \prime} \mathrm{N}$ & $89^{\circ} 55^{\prime} 34.2^{\prime \prime} \mathrm{E}$ \\
\hline 2 & Ward - 02 & Enayetpur & $24^{\circ} 16^{\prime} 32.5^{\prime \prime} \mathrm{N}$ & $89^{\circ} 53^{\prime} 42.5^{\prime \prime} \mathrm{E}$ \\
\hline 3 & Ward - 03 & Akutakur muslim para & $24^{\circ} 15^{\prime} 26.6^{\prime \prime} \mathrm{N}$ & $89^{\circ} 54^{\prime} 52.1^{\prime \prime} \mathrm{E}$ \\
\hline 4 & Ward - 04 & Bepari para (Mosque) & $24^{\circ} 14^{\prime} 32.1^{\prime \prime} \mathrm{N}$ & $89^{\circ} 56^{\prime} 02.2^{\prime \prime} \mathrm{E}$ \\
\hline 5 & Ward - 05 & Sakrail & $24^{\circ} 14^{\prime} 50.9^{\prime \prime} \mathrm{N}$ & $89^{\circ} 53^{\prime} 25.6^{\prime \prime} \mathrm{E}$ \\
\hline 6 & Ward - 06 & Amghat road & $24^{\circ} 14^{\prime} 35.8^{\prime \prime} \mathrm{N}$ & $89^{\circ} 53^{\prime} 20.5^{\prime \prime} \mathrm{E}$ \\
\hline 7 & Ward -07 & Bagbari & $24^{\circ} 14^{\prime} 08.0^{\prime \prime} \mathrm{N}$ & $89^{\circ} 53^{\prime} 48.3^{\prime \prime} \mathrm{E}$ \\
\hline 8 & Ward - 08 & Motherkhola & $24^{\circ} 13^{\prime} 35.5^{\prime \prime} \mathrm{N}$ & $89^{\circ} 53^{\prime} 24.5^{\prime \prime} \mathrm{E}$ \\
\hline 9 & Ward - 09 & Valukkandi (Mosque) & $24^{\circ} 13^{\prime} 46.9^{\prime \prime} \mathrm{N}$ & $89^{\circ} 54^{\prime} 13.5^{\prime \prime} \mathrm{E}$ \\
\hline 10 & Ward - 10 & Kazipur & $24^{\circ} 16^{\prime} 30.8^{\prime \prime} \mathrm{N}$ & $89^{\circ} 54^{\prime} 46.6^{\prime \prime} \mathrm{E}$ \\
\hline 11 & Ward -11 & Kandapara (Mosque) & $24^{\circ} 14^{\prime} 33.5^{\prime \prime} \mathrm{N}$ & $89^{\circ} 54^{\prime} 37.1^{\prime \prime} \mathrm{E}$ \\
\hline 12 & Ward - 12 & Adi Tangail & $24^{\circ} 15^{\prime} 40.5^{\prime \prime} \mathrm{N}$ & $89^{\circ} 55^{\prime} 08.2^{\prime \prime} \mathrm{E}$ \\
\hline 13 & Ward - 13 & East adalotpara (Pump) & $24^{\circ} 14^{\prime} 45.3^{\prime \prime} \mathrm{N}$ & $89^{\circ} 55^{\prime} 07.1^{\prime \prime} \mathrm{E}$ \\
\hline 14 & Ward - 14 & Biswashbetka & $24^{\circ} 15^{\prime} 37.7^{\prime \prime} \mathrm{N}$ & $89^{\circ} 55^{\prime} 37.9^{\prime \prime} \mathrm{E}$ \\
\hline 15 & Ward -15 & Ashikpur & $24^{\circ} 14^{\prime} 58.7^{\prime \prime} \mathrm{N}$ & $89^{\circ} 56^{\prime} 03.0^{\prime \prime} \mathrm{E}$ \\
\hline 16 & Ward - 16 & Pardighulia & $24^{\circ} 14^{\prime} 53.5^{\prime \prime} \mathrm{N}$ & $89^{\circ} 53^{\prime} 41.6^{\prime \prime} \mathrm{E}$ \\
\hline 17 & Ward - 17 & College para & $24^{\circ} 14^{\prime} 52.0^{\prime \prime} \mathrm{N}$ & $89^{\circ} 54^{\prime} 41.6^{\prime \prime} \mathrm{E}$ \\
\hline 18 & Ward - 18 & Sabalia & $24^{\circ} 15^{\prime} 44.2^{\prime \prime} \mathrm{N}$ & $89^{\circ} 55^{\prime} 02.2^{\prime \prime} \mathrm{E}$ \\
\hline
\end{tabular}


Table 2. Type of data sources used in the study

\begin{tabular}{|l|c|c|}
\hline Type of data source & Frequency & Percentage (\%) \\
\hline Tube-well & 15 & 83.3 \\
\hline Deep tube-well & 2 & 11.1 \\
\hline Pump & 1 & 5.6 \\
\hline Total & 18 & 100.0 \\
\hline
\end{tabular}

\section{Sample analysis}

To analyze the physicochemical properties of water, various standard methods were followed and a number of sophisticated instruments were used. A digital Global Positioning System (GPS) meter (GPSmap76 $\mathrm{cs}_{\mathrm{x}}$ ) was used to measure the position of the aquifers of water samples. Water color was observed by naked eyes and odor was felt with nose. A digital pH meter and Fast Sequential Atomic Absorption Spectrophotometer (VARIAN AA240FS, wave length of $248.4 \mathrm{~nm}$ ) was used to analyze the $\mathrm{pH}$ and $\mathrm{Fe}$ in the water samples, respectively.

\section{Data analysis}

The collected data were tabulated (data coding for analysis) and converted into the group of the aspects of Fe, $\mathrm{pH}$, color, odor and type of the sources. The qualitative data were converted into quantitative form. Statistical Package for Social Sciences (SPSS version 14.0) and Microsoft office excel 2007 was used to process and analyze the data. Many statistical tools, such as mean, median, mode, and standard deviation, were used to analyze data to identify the variables. Correlation and regression analysis were also performed in this research.

\section{Results and Discussions}

The odor and color indicated the purity of water. The pure water has no color and odor, and it is not turbid. The water was yellowish or slightly yellowish in few locations of the study area, while the water was odorless. The yellowish color of water generally indicated the presence of iron $(\mathrm{Fe})$ in the water. Though odor is not a direct indicator of the presence of $\mathrm{Fe}$ in water, sometimes odorless water can contain higher amount of $\mathrm{Fe}$. The concentrations of $\mathrm{Fe}$ in different locations of the study area were shown in Figure 1. The highest amount $(24.50 \mathrm{mg} / \mathrm{l})$ of Fe was found in Dewla north, while the lowest amount (1.03 $\mathrm{mg} / \mathrm{l}$ ) was found in Bepari para (Fig. 1). The higher amount of Fe concentrations, except the Dewla north, were also observed in Enayetpur $(16.21 \mathrm{mg} / \mathrm{l})$ and in Bagbari (19.19 mg/l), while comparatively lower concentrations were found in the other locations (Fig. 1). The ward wise observed $\mathrm{Fe}$ concentrations were shown in the Figure 2, where the highest and lowest amount of $\mathrm{Fe}$ was found in the ward 1 and 4, respectively. Nearly similar concentrations were also observed in the ward 2 and 7 (Fig. 2).

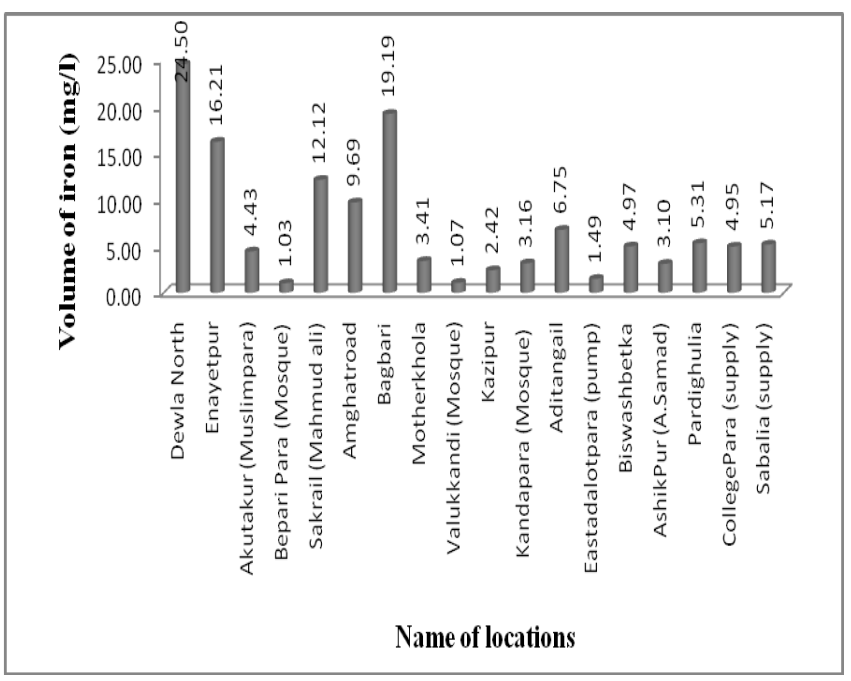

Fig. 1. Iron $(\mathrm{Fe})$ concentrations in different locations of the study area

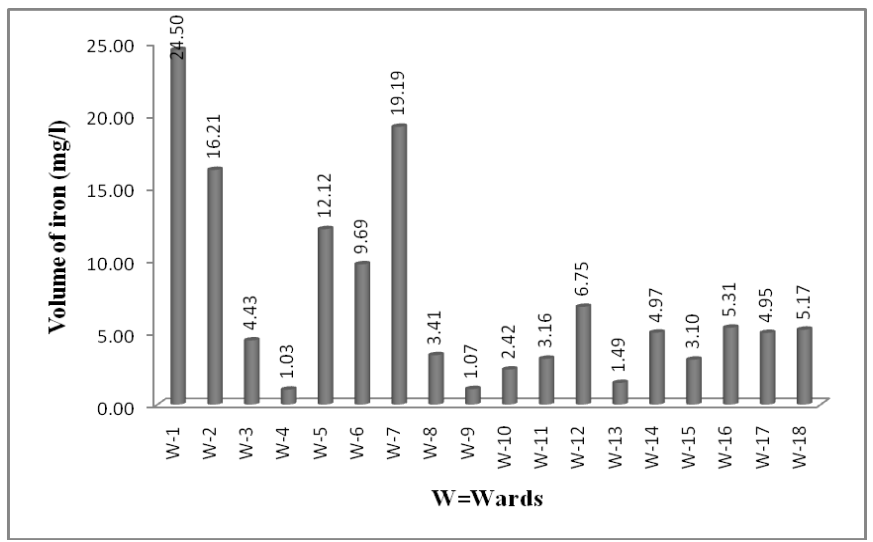

Fig. 2. Ward wise iron (Fe) concentrations in the study area. Note: $\mathrm{W}=$ Ward

It is found from the study that all of the samples were exceeded the standard levels of $\mathrm{Fe}$ of World Health Organization (WHO), Indian and Bangladesh standard, i.e. the sources of water are not suitable for drinking and uses for other purposes. The sign * indicates that the standard level of iron in Bangladesh is ranged from 0.30 to $1.00 \mathrm{mg} / \mathrm{l}$ (Fig. 3). Bangladesh Standard and Testing Institute (BSTI) and Indian standard level of $\mathrm{Fe}$ is $1.00 \mathrm{mg} / \mathrm{l}$, while WHO standard level is $0.3 \mathrm{mg} / \mathrm{l}$. That is, all of the ward's drinking water sources of Tangail municipality are more or less Fe affected, where the ward no. 1, 2, and 7 were worst affected (Fig. 3). 


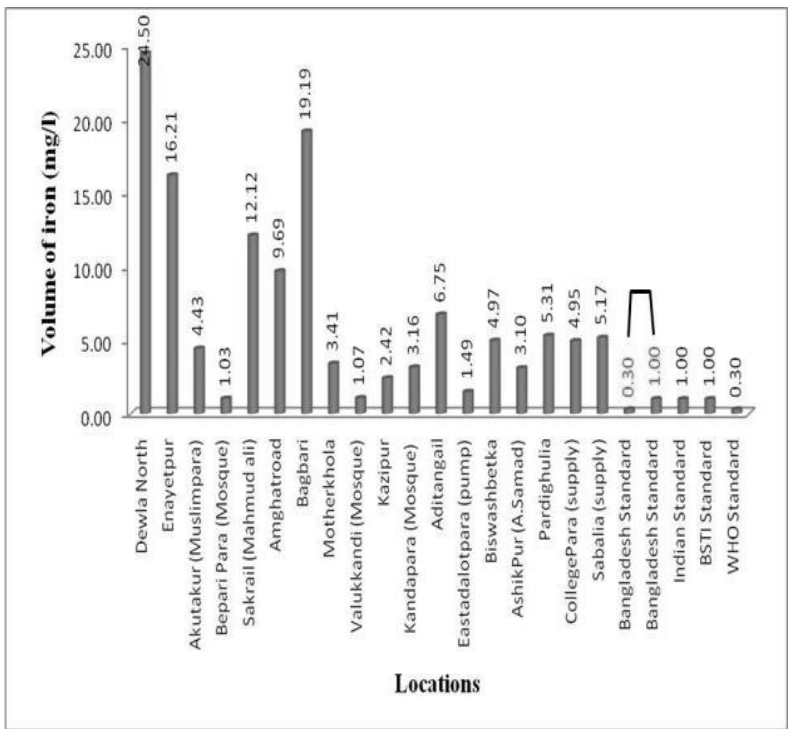

Fig. 3. Comparison of iron $(\mathrm{Fe})$ level between the study and the standards

The study showed that the lower $\mathrm{pH}$ value in groundwater held $\mathrm{Fe}$ in higher concentrations, thus there was a strong negative relationship between the $\mathrm{pH}$ and $\mathrm{Fe}$ in groundwater (Fig. 4). If the value of $\mathrm{pH}$ increases, then the concentration of $\mathrm{Fe}$ will decrease or vice versa.

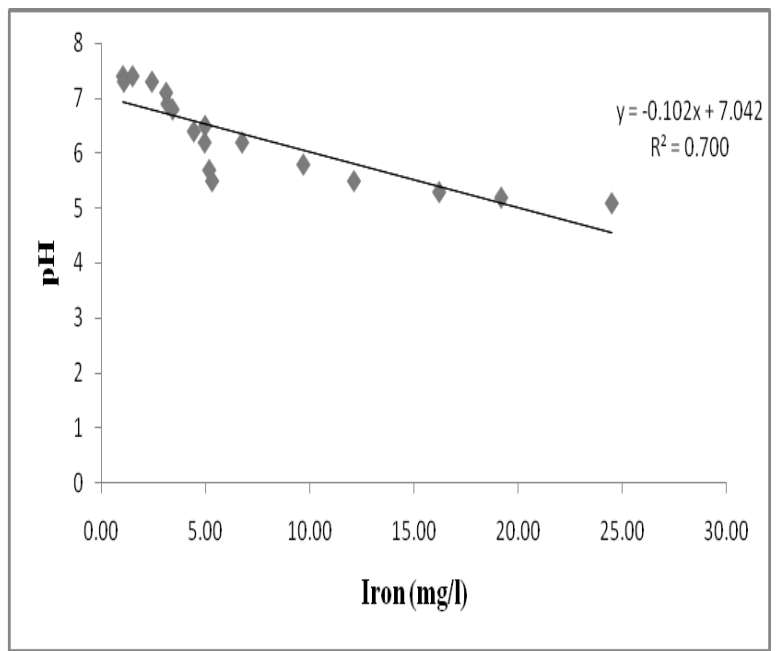

Fig. 4. Correlation between the $\mathrm{pH}$ and Iron $(\mathrm{Fe})$ in the study area

The study reveal that if the amount of Fe is high in the water, then the color of water is changed from white to reddish, and the trend line in Fig. 5 shows the positive correlation between the concentrations of $\mathrm{Fe}$ and color change with time. When the concentration of Fe increases, the color of water is gradually changed from white to yellowish to reddish.

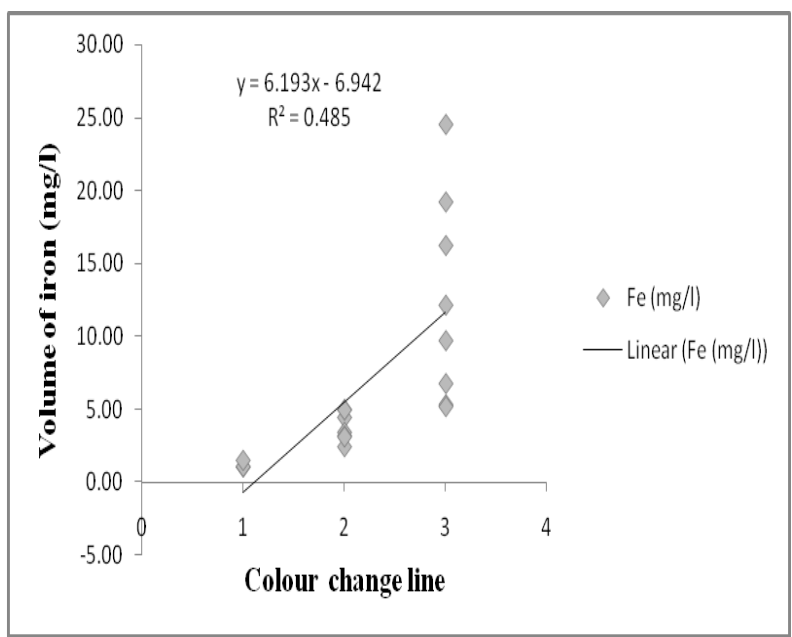

Fig. 5. Correlation between the concentration of Fe and change of water color with time

The cross tabulation of the concentrations of $\mathrm{Fe}$ and the type of data sources showed that two tube-wells were almost suitable for drinking purposes and others were not so (Table 3). It means that the availability of $\mathrm{Fe}$ in the water does not depend on the type of water sources, but it depends on the aquifers or water table. If the aquifer contains $\mathrm{Fe}$, then the tube-well water will contain $\mathrm{Fe}$. On the other hand, if the aquifer is free from $\mathrm{Fe}$, the water also may be free from $\mathrm{Fe}$ contamination.

These higher amounts of Fe found in the study area may be harmful for the member of those families who are using these water sources for their daily drinking and domestic purposes. Thus, the inhabitants of the study area should not drink these higher amounts of Fe to overcome this problem, and should also find other sources or replace the tube-well or treat the water before drinking and other domestic and household purposes. In Bangladesh, groundwater withdrawals are causing a large $\mathrm{Fe}$ contamination in groundwater levels during dry season (Ahmed and Rahman, 2000). As millions of people of Bangladesh rely on groundwater sources for their daily domestic and other purposes, the assessment of groundwater quality is one of the most important tasks. The results of such investigations can minimize different health related problems and can ensure a healthy life with safe drinking water sources. 
Table 3. Cross tabulation of $\mathrm{Fe}(\mathrm{mg} / \mathrm{l})$ and type of data sources

\begin{tabular}{|l|c|c|c|}
\hline \multirow{2}{*}{ Volume of iron $(\mathbf{m g} / \mathbf{l})$} & \multicolumn{2}{|c|}{ Type of data sources } \\
\cline { 2 - 4 } & Tube-well & Deep tube-well & Pump \\
\hline $1.00-1.70$ & 2 & 0 & 1 \\
\hline $2.40-3.10$ & 1 & 0 & 3 \\
\hline $3.10-3.80$ & 2 & 0 & 1 \\
\hline $3.80-4.50$ & 2 & 0 & 0 \\
\hline $4.50-5.20$ & 1 & 1 & 0 \\
\hline $5.2-5.90$ & 1 & 1 & 0 \\
\hline Above 6.60 & 6 & 0 & 2 \\
\hline Total & 15 & 2 & 0 \\
\hline
\end{tabular}

\section{Acknowledgements}

We express our sincere thanks to Mr. Md. Aminul Ahsan (SSO) and Mr. Md. Mamunur Rashid (SSO) of Analytical Research Division in BCSIR, Dhaka-1205, for their kind suggestions, recommendations and considerations during the study period. We also acknowledge the Tangail municipality authority to allow us to use and incorporate their information's into the study.

\section{References}

Ahmed, M. F. and Rahman, M. M. 2000. Water supply and sanitation, Specific groundwater treatment process. Centre for water supply and waste management, BUET, Dhaka, Bangladesh, Section 19.3, pp: 371-405.

Anon. 1970. Groundwater pollution. Water Well Journal, 24(27): 31-61.

Anonymous, 2004. Water: A millennial priority. The Acme Agrovat and Beverage Ltd., Dhaka, Bangladesh.

APHA (American Public Health Association). 1998. Standard methods for the examination of water and wastewater, $19^{\text {th }}$ edn. American Public Health Association, Washington DC, USA.

Azad, A. K. 2003. Impacts of Farakka Barrage on surface water resources in Bangladesh, World Environment Day, Report of Department of Environment, Government of the People's Republic of Bangladesh, pp: 40-43.

Bader, J. S. 1973. Ground-water contamination, The United State of America and Puerto Rica, U. S. Geological Survey, Washington DC, USA, pp: 103.

Ballentine, R. K. 1972. Subsurface pollution problems in the United States, Tech. Studies Rept. TS-00-72-02, U. S. Environmental Protection Agency, Washington DC, USA, pp: 29.
Banglapedia. 2008. National Encyclopedia of Bangladesh, Asiatic society of Bangladesh.

Barnes, I. and Clarke, F. E. 1964. Geochemistry of groundwater in mine drainage problems, $\mathrm{U}$. S. Geological Survey Prof. Paper 473-A, pp: 6.

Elinder, C. G. 1986. Iron, In: Friberg L., Nordberg G. F., Vouk V. B., eds, Handbook on the technology of metals, V. II, Amsterdam, Elsevier, pp: 276-297.

Emrich, G. H. and Merritt, G. L. 1969. Effects of mine drainage on groundwater. Ground Water, 7(3): 27-32.

Gunatilaka, A. 2005. Groundwater woes of Asia, Asian Water, January/February.

Kneeper, W. A. 1981. Iron, In: Kirk-Othmer encyclopedia of chemical technology, V.13, New York, USA, Wiley Interscience, pp: 735-753.

Meyer, C. F. 1973. Polluted ground: Some causes, effects, controls, and monitoring. Rept. EPA600/4-73-0016, U. S. Environmental Protection Agency, Washington, D. C., USA, pp: 282.

Mink, L. L. 1972. Effect of early day mining operations on present day operation water quality, Groundwater, 10(1): 17-26.

Rukshana, F.; M. N. Haque, M. H. Mazumder, S. R. Chowdhury, G. U. Ahmed and Quadir, M. E. 2002. Arsenic investigation of drinking water in some area of Faridpur district. Tech. Journal, 9(2): 99-107.

Sattar, M. A. 1998. Agrochemical contamination in Bangladesh soils. Pub. Aksat RPI, ISBN 98431-1058-7, pp: 100.

WARPO (Water Resource Planning Organization). 2000. Main report, v.2, National Water Management Plan Project, Ministry of Water Resource, Government of the People's Republic of Bangladesh. 